\title{
Liberals versus conservatives: Are attitudes toward government related to experiences with government?
}

\author{
HENRY B. SIRGO and RUSSELL EISENMAN \\ McNeese State University, Lake Charles, Louisiana
}

\begin{abstract}
Attitudes toward local, state, and federal governments were studied in 25 liberals and 25 conservatives who had shown a social interest in politics by making financial contributions to political parties. Their positive or negative experiences with these governments were also assessed. Consistent with Katz et al. (1975), the subjects tended to hold negative views of government even if their personal experiences were positive. Thus, rewarding experiences do not necessarily lead to positive views toward the object of reward. However, this was more true of the liberals than of the conservatives.
\end{abstract}

The importance of having social interests has been emphasized by Adler (Ansbacher \& Ansbacher, 1956). According to the editor's note in Ionedes (1989), "social interest" is the usual translation for the German word Gemeinschaftsgefühl, which Adler used, meaning one's feelings of being not only a member of the community but a "shaper" as well. Recently, we have investigated various aspects about people who show a shaping quality to their community membership. Specifically, we have looked at liberals and conservatives who make financial contributions to political campaigns (Eisenman \& Sirgo, 1991; Sirgo \& Eisenman, 1990). Such behavior shows an involvement in political matters beyond merely favoring one candidate over another, or favoring no one.

Although liberals and conservatives have been found to differ from each other in important ways (Eisenman \& Sirgo, 1991; Furnham \& Heaven, 1988; Himmelstein \& McRae, 1988; Jones \& Iacobucci, 1989; Kiecolt \& Nelson, 1988; Ray \& Furnham, 1984; Rinehart \& Perkins, 1989; Sirgo \& Eisenman, 1990), Eisenman and Sirgo (1991) found that liberal and conservative financial contributors were alike in that both had high autonomy and self-esteem. Perhaps an active involvement in community affairs is consistent with feelings of well-being, which is consistent with the Adlerian view of social interests (Ansbacher \& Ansbacher, 1956).

The present study sought to find out how financial contributors view government and whether this view is related to their personal experiences with government. It might be assumed that people who have had positive, rewarding experiences with government will have positive views toward government, and that people who have had

Address requests for reprints to either author: H. B. Sirgo, Department of Social Sciences, McNeese State University, Lake Charles, LA 70609-2335 or R. Eisenman, Department of Psychology, McNeese State University, Lake Charles, LA 70609-1895. negative, punishing experiences will have negative views. However, Katz, Gutek, Kahn, and Barton (1975) found that even people who had positive interactions with government agencies often had negative views of government. So, this part of the seemingly obvious prediction did not hold up. However, negative experiences with government did correspond to negative evaluations of government. What may be happening is that people hold negative views of government, and thus their attitudes will be negative, regardless of their personal experiences.

The federal government is the most powerful governmental agent in our lives, our local governments are the ones that we are most likely to deal with on a day-to-day basis, and in between are our state governments. We looked at the experiences that people had had with these three governments and what their attitudes were toward them. We supposed that, because our sample was politically active, they might show a more consistent relationship between personal experiences with the government and attitudes about the government than did the subjects in the Katz et al. (1975) study.

\section{METHOD}

\section{Subjects}

The names of financial contributors to statewide political races are public records and freely available. Fifty names were randomly chosen from the state's list and these contributors were asked to participate. In an attempt to obtain 25 liberals and 25 conservatives, 25 names were randomly chosen from Democratic contributors and 25 from Republican contributors because Eisenman and Sirgo (1991) have found a statistically significant tendency for Democrats to be liberals and Republicans to be conservatives. All the subjects agreed to participate and were interviewed using the measures discussed below. The subjects tended to be of high socioeconomic status, based on occupation, income, years of education, and father's income.

\section{Procedure}

All the interviews were either tape recorded or written out by the experimenter, with the permission of the subjects. If tape recorded, a small cassette recorder with a built-in microphone was used, to be as unobtrusive as possible. 


\section{Measures}

Two measures of liberalism-conservatism were used to classify the subjects as either liberal or conservative. The first was a liberalismconservatism measure from Owens (1967), with two modifications. One item was eliminated because it was considered to no longer show differences between liberals and conservatives (an item about the government sponsoring research for a cancer cure, which conservatives now endorse). Another item was changed by inserting the word social before programs, so that the question would deal with social programs of the government and not all governmental programs. The second measure was the presentation of issues, seven made up for this study, with which subjects were asked to agree or disagree. These were all domestic issues, such as gun control or government support for mass transit (people tend to hold more reliable views on domestic issues than they do on foreign-policy issues). The subjects were classified as either liberal or conservative on the basis of their combined scores on the two measures, which correlated .80 .

The participants were asked 24 questions about their personal experiences with governmental agencies. There were also 11 potential follow-up questions, depending on the answers the subjects gave to the first set. All the responses were rated on scales as being positive or negative experiences. For subjects' perceptions of government, three basic questions were additionally asked, along with three more follow-up questions, depending on their answers. These responses, too, were scored as either positive or negative toward the government. All positivenegative rating scales were established before the interviews, so that answers could be placed on the positive-negative dimension of alreadyavailable rating scales.

\section{RESULTS}

All statistical results reported here are two-tailed binomial probabilities, taken from the table in Siegel (1956). Because Siegel gives one-tailed probabilities, his numbers have been doubled to report two-tailed tests. The two measures of liberalism-conservatism (and the selection method) yielded 25 liberals and 25 conservatives.

For local government, 10 of the liberals reported negative experiences with government and also considered local government to be unfair $(p=.002)$. However, 15 of the liberals reported having positive experiences with local government, but 12 nevertheless considered local government to be unfair $(p=.036)$. These results are totally consistent with Katz et al. (1975). However, there was no relationship between positive or negative experiences with local government and positive or negative attitudes toward local government for the conservatives.

For state government, the findings were similar. There was no relationship between experience with government and perception of government for the conservatives; for the liberals, the results were similar to those for local government, but they did not reach statistical significance.

For federal government, the liberals again tended to have negative attitudes toward government regardless of their experiences, but like the state government data, the results did not reach statistical significance. For the conservatives, there was no relationship between favorable experiences with federal government agencies and considering the federal government to be fair or unfair. However, 10 of the conservatives reported unfavorable experiences with the federal government, and all but 1 had the attitude that the federal government is unfair $(p=.002)$.

\section{DISCUSSION}

These results show that there seems to be a pervasive negative view of government; even when the subjects' experiences with governmental agencies were positive, they still adhered to a negative view of government. The present findings are similar to Katz et al. (1975). However, our findings suggest that the Katz et al. findings might hold up better for liberals than for conservatives. Perhaps liberals have a more critical view of the establishment, so that even positive personal experiences with the government will not translate into positive attitudes.

Our sample was one of activists, in the sense that they were financial contributors to political candidates. Also, they were of at least middle socioeconomic status. We might think that such people would have favorable views about the government, as opposed to those more alienated from the political system because of low social interest, destructive social forces (poverty), or extreme distrust of government. However, the findings are that even socially involved people of high socioeconomic status tend to have negative views of the government and that these negative views are not changed by positive experiences.

Perhaps these negative views are the motivation for political involvement. It may be that social interests sometimes correlate with a dissatisfaction about aspects of a person's life, and that person could then take an active interest in trying to change things, by becoming a political activist. In the present sample, political activism involved financial contributions but there are other forms of political activism, such as registering voters, making speeches, serving on committees, and so forth.

It may be that the relatively small sample size in the present study25 liberals and 25 conservatives-resulted in some nonsignificant findings. A future study with more subjects might result in some of the trends being statistically significant. Also, it may be that conservatives would be dissatisfied with certain aspects of government, such as government support for minorities (Sirgo \& Eisenman, 1990). Thus, a study that focused on certain specific topics might show different results, as would a study in a situation in which liberals held political power and conservatives were the outgroup. People who lack power often feel bad about their society, feel bad about themselves, and are stigmatized by others (Eisenman, 1991). Thus, different results might obtain if another study focused on specific topics of particular concern to liberals or conservatives.

\section{REFERENCES}

Ansbacher, H. L., \& Ansbacher, R. R. (EDS.). (1956). The individual psychology of Alfred Adler. New York: Basic Books.

Eisenman, R. (1991). From crime to creativity: Psychological and social factors in deviance. Dubuque, IA: Kendall/Hunt.

Eisenman, R., \& Sirgo, H. B. (1991). Liberals versus conservatives: Personality, child-rearing attitudes, and birth order/sex differences. Bulletin of the Psychonomic Society, 29, 240-242.

Furnham, A., \& Heaven, P. C. (1988). The paradox of socialism: The relationship between social and economic political beliefs. Psychological Reports, 62, 327-332.

Himmelstein, J. L., \& McRae, J. A. (1988). Social issues and socioeconomic status. Public Opinion Quarterly, 52, $492-512$.

IONEDES, N. S. (1989). Social interest psychiatry. Individual Psychology, 45, 416-423.

JoNES, L. E., \& IACOBUCCI, D. (1989). The structure of affect and trait judgments of political figures. Multivariate Behavioral Research, 24, 457-476.

Katz, D., Gutek, B. A., Kahn, R. L., \& BARTon, E. (1975). Bureaucratic encounters: A pilot study of evaluation of government services. Ann Arbor, MI: Institute for Social Research.

KIECOLT, K. J., \& Nelson, H. M. (1988). The structuring of political attitudes among liberal and conservative Protestants. Journal for the Scientific Study of Religion, 27, 48-59. 
OWENS, W. H., JR. (1967). An operationalized conceptualization of selected ideological variables in the perspective of liberalism and conservatism. Unpublished doctoral dissertation, Florida State University, Tallahassee.

Ray, J. J., \& Furnham, A. (1984). Authoritarianism, conservatism, and racism. Ethnic \& Racial Studies, 7, 406-412.

Rinehart, S. T., \& Perkins, J. (1989). The intersection of gender politics and religious beliefs. Political Behavior, 11, 33-56.
SIEGEL, S. (1956). Nomparametric statistics for the behavioral sciences. New York: McGraw-Hill.

Sirgo, H. B., Eisenman, R. (1990). Perceptions of governmental fairness by liberals and conservatives. Psychological Reports, 67, 1331-1334.

(Manuscript received October 23, 1992.) 